\title{
Liberal international criminal law and legal memory: deconstructing the production of witness memories at the International Criminal Tribunal for Rwanda
}

\section{Benjamin Thorne}

Abstract: International criminal tribunals and courts, such as the International Criminal Tribunal for Rwanda (ICTR), are commonly understood within legal transitional justice scholarship as the primary response to mass human rights violations, not only in addressing impunity, but also in uncovering the truth of what happened and why. This conceptually orientated article aims to deconstruct legal witnessing and memory production at the ICTR in order to critique claims in legal scholarship that international criminal institutions are able to produce a collective memory of mass rights violations. Specifically, the article proposes an original conceptual framework using insights from critical theory, Giorgio Agamben (witness) and Paul Ricœur (memory), which it is argued extends our understanding of the scope, and limitations, of liberal Western criminal institutions' (in)ability to make sense of past atrocities.

Keywords: International criminal institutions, critical theory, legal memory construction.

Note on the author: Dr Benjamin Thorne's main areas of interest are socio-legal studies, transitional justice, and critical theory. Currently a central focus is memory, transitional justice, and legal atrocity archives. More generally, Benjamin is interested in questions around visual and audio representations of crime, law and justice, and the coexistence of spaces of law and faith in the aftermath of mass violence.

(C) The author(s) 2021. This is an open access article licensed under a

Creative Commons Attribution-NonCommercial-NoDerivs 4.0 Unported License 


\section{Introduction}

This conceptually orientated article proposes an original theoretical framework to critique liberal international criminal law and specifically the claim that international criminal courts and tribunals can aid African societies transitioning from conflict and atrocities by producing, via the testimonies of witnesses, a collective understanding of why and how the atrocities occurred. To do this it uses the case study of the International Criminal Tribunal for Rwanda (ICTR), which was created as an international response to the 1994 genocide against the Tutsi in Rwanda. The article's critique is framed by the backdrop of transitional justice's strong legalistic orientation (Zunino 2018), in both an empirical and a philosophical sense: international criminal justice is seen as superior and more 'neutral' to local understandings of justice, and international criminal courts and tribunals are perceived to be the primary way to facilitate this Western liberal notion of justice (Dixon \& Tenove 2013). Transitional justice's orientation towards the primacy of international criminal justice has a fetishisation with Africa (Murithi 2008, Nkansah 2011, Nyawo 2017, Clarke 2019, Muleefu 2019). This fixation has consistently lacked understanding and engagement with societies experiencing periods of transition, which has often led to a negative rather than positive impact on those that international justice is purportedly aiming to help (Igwe 2008, Nyawo 2017, Clark 2018). Advocates of international criminal justice as the most suitable response to atrocities and/or conflict in Africa commonly claim the scope of international criminal law to contribute to societal transformation (Kendall 2015, Keydar 2019). The crux of this claim is that international criminal courts and tribunals have the ability to go beyond the essence of what courts are there to do, that is reach a legal determination of guilty or not guilty, and can also contribute to reconciliation and peace (Igwe 2008, Keydar 2019). These lofty and idealised aims of international criminal law include contributing to producing a collective understanding of the past through the testimonies of witnesses.

From this backdrop, the article proposes an original conceptual framework using insights from Giorgio Agamben ('witness') and Paul Ricœur's philosophical thinking on memory, in order to deconstruct the ways in which the ICTR constructs witness identity and memories. Agamben's (1999) understanding of witnessing is concerned with the ethical implications of positioning the survivor of mass violence as the witness, accounting for the trauma suffered by others. Agamben's concept of 'witness' focuses on the concentration camps at Auschwitz. This article takes Agamben's conceptual insights and applies them to a new context, the ICTR. Ricœur (2004) understands memory to be plural and fragmented, unable to render the temporality of historical knowledge. The arguments advanced by this article contribute towards discussions on the role of witnesses and how the past is remembered during transitional 
periods, by highlighting the need for the study and practice of transitional justice to fully understand how theoretical insights can make visible the complexities, contours, and limitations of the legal construction of past experiences of African societies.

This article aims to advance three related points. The discussion begins by providing a summary survey of liberal orientated legal scholarship which claims the ability and benefits of international criminal courts and tribunals to be able to produce a collective understanding of how and why the atrocities occurred. The section argues that this scholarship is saturated with traditional legal frameworks and epistemological assumptions, and misses, or is conceptually unable to comprehend, the contingent nature of legal memory construction and the role legal institutions, and their actors (judges, legal counsel, investigators, registrar) play in the construction of witness identity and memories. Developing this argument, the second section of the article constructs an original post-structuralist conceptual framework for exploring identity and memory construction at the ICTR specifically, and international criminal courts generally. The article proposes that this conceptual framework offers an alternative understanding of who can be a witness at the ICTR and what witnesses can recall from their memories. The section concludes by arguing that this framework offers one way to consider legal witnessing and memory as a process of construction, limits, and exclusion. The final section reflects on Rwandan society's relationship with legal memory by conceptually exploring what else the legal process of memory construction does: what else happens or is produced through the discursive practices at the ICTR. Specifically, it provides an initial exploration of the potential role ICTR archival material could have in aiding post-conflict memory ecology in Rwanda.

\section{Context and scope}

Between April and July 1994 in Rwanda approximately 800,000 people were killed, mainly ethnic Tutsi and moderate Hutu. The ICTR was created (United Nations Resolution 955, 1994) following a request led by the Rwandan government (Rwandan Patriotic Front (RPF)) and a United Nations investigation that concluded the violence between April and July 1994 was genocide. The preamble in the ICTR statute states the establishment of the tribunal will bring a new era to international criminal justice and individual accountability for violations of international law, including genocide (ICTR 2007: 55). The statute also states that the tribunal will contribute towards the 'process of national reconciliation and to the restoration and maintenance of peace' (ICTR 2010: 57-9). The tribunal was comprised of three organs: the chambers, the prosecutor, and the registry. The tribunal's first judgment was delivered on 2 September 1998 (Jean Paul Akayesu). The average length of a trial (from indictment issued to judgment) 
was just under 8.5 years, though the longest ICTR trial was more than double the average at 19.5 years (Elie Ndayambaje). During the tribunal's 21-year existence (1994-2015) it issued 93 indictments and delivered 62 sentences. ${ }^{1}$ It is also perceived by many advocates of international justice as producing 'landmark' judgments, such as in the Akayesu case which determined for the first time rape as a weapon to commit genocide. Alongside this advocacy, the ICTR has also been criticised for delivering 'one-sided justice', specifically for not indicting any members of the RPF for crimes committed within the tribunal's jurisdiction (Jones 2009). A common response to this claim by the Rwandan government is that members of the RPF who committed crimes have been tried in Rwandan military courts, albeit 'closed door' proceedings with few publicly available records. Although, former ICTR prosecutor Hassan Bubacar Jallow has stated that the government had shown him details of up to 24 senior military officers who had been prosecuted by the Rwandan military courts in relation to allegations against the RPF (Jallow 2009). ${ }^{2}$

The ICTR was one of three transitional justice responses to the same historical event in Rwanda. This consisted of an international mechanism, the ICTR; at the national level there were the Rwandan courts; and at a local level the community gacaca courts. Palmer (2015) has coined the term 'concurrent justice' for multiple legal institutions responding to the same mass atrocity. In principle, these three justice mechanisms were designed to work collegially and support each other's work and operations (Palmer 2015). However, Palmer has argued that in practice, despite the legal compatibility of the courts, these three mechanisms operated in competition and with a cynical view of the workings of the other courts (Palmer 2015: 3-5).

Witness evidence was central to the functioning of all three of the courts, resulting in nearly every Rwandan adult engaging with one of these legal mechanisms, sometimes two or even in occasional instances all three (Palmer 2015: 4). At the ICTR's core were investigations carried out by prosecution and defence counsels where tens of thousands of witness statements from individuals who had survived the violence were gathered. This article's framework (Agamben and Ricœur) is used to deconstruct witness identity and memory construction at the ICTR, including the pretrial stage. To help contextualise these conceptual arguments, the article engages with data from interview transcripts of ICTR staff that relate to the selection of witnesses, including legal counsel, registrar, and investigators. The interview transcripts were taken from the University of Washington online archive. These interviews were conducted by the

${ }^{1}$ In 2010, the United Nations Security Council created the International Residual Mechanism for Criminal Tribunals to continue some of the core functions of the ICTR, and International Criminal Tribunal for the Former Yugoslavia, including prosecuting indictments issued by the ICTR and appeal proceedings.

${ }^{2}$ See Jallow's statement to the UN Security council (2009, https://undocs.org/en/S/PV.6134). 
UoW Faculty of Law (2008-9) for their project 'Voices from the Rwanda Tribunal' (VFRT), and include the full transcripts, audio and video recordings of the interviews, along with all of the questions the interviewees were asked. The online archive contains 49 interviews with ICTR personnel, including judges, acting chief of investigations, legal officers, prosecution and defence counsel, investigators, and the chief of information. The University of Washington's project was created for the purpose of establishing an online archive of information with the intention that it be reused and repurposed by others, including Rwandans, researchers, artists, and educators (Nathan et al. 2011: 593). The interview transcripts provide very useful information about first-hand experiences of the functioning of the tribunal relating to the selection of witnesses.

This article is not arguing that the benefits of international criminal proceedings, or the role international criminal courts have in the growing milieu of transitional justice responses to periods of violence, should be rejected. What this article is sceptical of and challenges throughout the following conceptually orientated critique, is the claim of restorative justice capabilities of international criminal law. Specifically, the claimed capability that international criminal courts can, and should, go beyond their retributive duty to bring about accountability for heinous crimes, and can also contribute to aiding affected societies in Africa by producing a collective understanding of the past.

\section{International criminal justice as the purported panacea for conflict and atrocities in Africa}

This section begins with a discussion of how liberal international criminal law has become an entrenched norm for transitional justice responses to atrocity crimes in Africa. Expanding this discussion, the section then gives a summary survey of how this dominant approach has impacted the perceived ability of international criminal courts and tribunals to be able to produce a collective understanding of past horrors.

In the context of conflict and/or mass atrocities in Africa, liberal international criminal law has become a dominant sphere that shapes the priorities and processes for how transitional justice responds to atrocity crimes (Zunino 2018: 2). A core feature of this sphere is a Western understanding of the universality of legal and human rights norms. In short, legal norms are a set of 'Western' legal values that espouse the existence of a standardised framework of criminal law which functions as a universal paradigm for the international community (Teitel 2015: 56). The reverence for legal and human rights advocacy has influenced the perceived importance of international criminal law in transitional justice scholarship (McEvoy 2007). International criminal 
and human rights law acts as a universal standard which can 'provide guidance on the necessary course of action', which is external to the parties involved in transition (Turner 2013: 200). However, transitional justice defined by legal and human rights norms, homogenises the way in which periods of transition are comprehended. This homogenising perceives that there is one, indisputable, understanding of justice through which past atrocities can be understood and addressed (Turner 2016). Thus, this singular understanding of justice acts to carve a paradigm of legitimacy for transitional justice legal mechanisms, which, importantly, comes at the cost of withdrawing heterogeneous meaning during periods of transition. This is reflected in Turner arguing, it is '[p]recisely because of the inevitable disagreement over the meaning of justice in transitional societies, [international criminal] law steps in to replace politics as the basis for authoritative decisions' (Turner 2013: 205). As a result of international criminal law colonising what constitutes legitimate meaning, alternative understandings of justice are marginalised from the debate (Turner 2013: 199-201). For example, the Rwandan gacaca courts (2002-12) have been labelled as a 'failed' process by much of legal scholarship, precisely for not falling within the legal paradigm of legitimate approaches, even though many Rwandans interpret gacaca in different ways (Doughty 2016, 2017, Thorne \& Viebach 2019). ${ }^{3}$ Thus, transitional justice scholarship in dealing with the past and as a legitimating source for a democratic domestic future is founded upon the 'assumption of the capacity of international criminal law to mediate social change' (Turner 2013, 198-9).

International criminal justice resonates with the dominance of legal and human rights norms as the panacea of transitional justice in Africa. One of the implications of this dominance is that the International Criminal Court (ICC) is often charged with being a neocolonial institution, partly because it has only issued indictments for atrocities in Africa. Although, Phil Clark has argued that, whilst there is validity in the neocolonial perspective of the ICC, this argument overstretches the view that African governments are completely at the 'mercy' of the ICC and that states are powerless to resist this international justice institution (Clark 2018). As Clark argues, contrary to the common perception that the ICC wields unrestricted power over situation countries in Africa, rather some African governments, such as in Uganda, have used the ICC for their own political ends precisely because the court is a weaker institution than is often acknowledged (Clark 2018: 119). This emphasises the complexities between courts' engagement with African conflicts and the political dynamics of these countries.

According to Kamari Maxine Clarke, international criminal justice is an assemblage of legal technocritical practices, embodied effects, and emotional regimes, 
which she refers to as 'affective justice' (Clarke 2019: 9). This assemblage of affective justice creates possibilities and conditions for the way that international justice engages with African countries: how justice is defined, who is it for (and not for), and its geographical reach (Clarke 2019: 6). Affective justice helps us understand 'people's embodied engagements with and production of justice through particular structures of power, history and contingencies' (Clarke 2019: 5). A key part of Clarke's affective justice is the 'victim' subject, through which the workings of the international criminal court (ICC) and structures of power are embodied. It is the 'legalistic processes that make legible the subjects of the law', such as victims (Clarke 2019: 29). Here, in the context of this article we can think of legal witnesses as one of the subjects of law, whose subjectivity and voice are made possible and conditioned through the discursive practices of the ICTR and its legal actors. Understanding the conditions and possibilities of who can be a witness and what they can recall from their memories at the ICTR is the central thrust of the original conceptual framework offered in the discussions to follow.

It is this frame of advocacy for international criminal justice and legal and human rights norms that advocates often use to justify the ability of international criminal courts and tribunals to produce a collective understanding of mass atrocities in Africa. Scholarship focusing on the role of legal witnessing in international criminal courts can be split broadly into two approaches, traditional legal frameworks and legal and human right norms, although they are not necessarily mutually exclusive. Traditional legal frameworks have primarily focused on procedural processes of witness evidence, particularly on the role and legitimacy of witness proofing (Ambos 2009). Relatedly, Combs has argued that at the ICTR Rwandan witnesses were often untrustworthy and had a 'culture' of secrecy (Combs 2010). However, Combs focuses exclusively on 'culture', how Rwandan culture shapes how witnesses engaged with the ICTR. Combs fails to acknowledge the important role that legal culture and practices of the ICTR had in shaping the testimonies of witnesses (Eltringham 2019: 137). Scholars who analyse legal witnessing through the lens of legal and human rights norms argue that they contribute on an individual level by enabling witnesses to come to terms with the past (Kim 2013: 40, Klinkner \& Smith 2015) and at a collective level through the compilation of witness testimonies facilitating a collective memory of mass violations (Keydar 2019). Groome argues that, on an individual level, there is a need to position individual victims of mass human rights violations at the centre of legal responses to atrocities, transitioning victims from passive sufferers of violence to active participants in processes of redress (Groome 2011). Those who claim the beneficial relation of legal approaches to understanding the past and human rights norms argue it aids individuals and 'satisfies society's interest in the truth about gross violations of human rights' (Groome 2011: 198). However, this human rights discourse on witness memories 
fails to comprehend the conditional and contingent nature of memory. This is because there exists a fundamental principle within normative human rights discourse that individual victims of rights abuses have a universal right to agency in legal proceedings (Klinkner \& Smith 2015: 11-12). This normative human rights discourse 'often leads to "faith-based" rather than "fact-based" prescriptions" (Thoms et al. 2008: 5). As such, this suggests that expectations of human rights advocacy are often too high, which exemplifies the need to conceptually examine how individuals 'become' a witness subject and the institutional conditions and possibilities of how they remember.

\section{Conceptualising the way ICTR witnesses remember mass atrocities}

This section constructs an original theoretical framework using the concepts of 'memory' (Ricœur) and 'witness' (Agamben). The article's framework uses a 'toolkit' approach to theoretical insights, in which particular conceptual components are brought together as a conceptual lens to cast new light on a given research problematic (Foucault 1972). This conceptual framework consists of five interconnected components: namely, subjectivity, the grey zone, the lacuna of law-justice (Agamben), plurality of memory, and manipulated memory (Ricœur). In what follows each conceptual component is outlined and applied to the ICTR. Each conceptual insight builds upon the others in order to create a lens through which witness identity and memories at the ICTR can be deconstructed.

\section{The subjectivity of bearing witness}

Reflecting on the achievements of the ICTR, Deputy Registrar Everard O'Donnell is a voice that champions how the tribunal has been able to tell victims' stories of horrific suffering that would not otherwise be heard. In exemplifying his conviction, O'Donnell draws upon the Mikaeli Muhimana (ICTR-95-1B) case and the horrific events that led to the torture and murder of Pascasie Mukaremera and her unborn baby:

Pascasie Mukaremera who was this Tutsi farmer who was pulled out, tortured and had her baby ripped out of her stomach and we would never have known about that if it hadn't been for just one witness who was hiding in the bushes 20 meters away. Otherwise it would be an anonymous death, you know, like so many of the hundreds of thousands of deaths, just anonymous. We have recorded Pascasie Mukaremera's story for the rest of time. Wherever digital media survives, that witness will be able to speak. 
O'Donnell's remarks that legal witnesses can tell the stories of horrific trauma is at the centre of this article's conceptual investigation.

According to Agamben, there are two types of witnesses at Auschwitz. The witness who was killed at Auschwitz and the witness who survived and was left to tell the story of Auschwitz to others (Agamben 1999: 16). For Agamben, these two types of witnesses are an instructive 'paradigm' for thinking through, ontologically, how experience (knowledge) is understood (Agamben 1999). That being so, interrogating the lacuna in which 'survivors bore witness to something it is impossible to bear witness to' (Agamben 1999: 13). This is why Agamben insists the central concern of his book, Remnants of Auschwitz, is testimony (Agamben 1999: 13). ${ }^{4}$ According to Agamben this lacuna of the impossibility for the survivor to bear witness is clearly evident in Primo Levi's account of his own experience of surviving Auschwitz (Agamben 1999: 16-17). Specifically, Agamben uses Levi's account in The Drowned and the Saved as the ontological foundation for thinking through how the experience, and more specifically knowledge, of Auschwitz can be known if it is impossible for the survivor to bear witness to it (Agamben 1999). Therefore, it is necessary for the discussion that follows to briefly summarise Levi's The Drowned and the Saved, then to go on to unpack how Agamben uses it to develop his philosophical understanding of witnessing and how the article uses it.

A central theme of The Drowned and the Saved is the survivors' responsibility to speak, ensuring the atrocities of Auschwitz were not forgotten, and simultaneously coping with the guilt of having survived the camps when so many did not. On bearing witness to the memory of Auschwitz and a moral obligation to do so, Levi is clear on one thing: as a survivor of the camps Levi accepts the moral obligation to testify to what he witnessed. However, Levi is unequivocal that the true witnesses to the horrors of the Nazi concentration camps were those killed in the gas chambers (Levi 1988). Here it is worth stating at length Levi's conviction on his understanding of the true witnesses:

I must repeat -we, the survivors, are not the true witnesses. This is an unfortunate notion, of which I have become conscious little by little, reading the memories of others and reading mine at the distance of years. We survivors are not only an exiguous

\footnotetext{
${ }^{4}$ Remnants of Auschwitz forms the third instalment of Agamben's Homo Sacer project, though it is this third instalment in particular that received heavy criticism for its apparent deemphases of historical singularity (Bernstein 2004, Marion 2006, Mouffe \& Laclau 2007). Although such criticism overlooks the nuances of the philosophical method Agamben employs. What critics including Laclau, Marion, and Bernstein appear to be challenging most of all, albeit Marion and Bernstein from a slightly different position to Laclau, is the paradigmatic method Agamben uses to make his philosophical offerings. This criticism stemmed from Agamben's use of Auschwitz and figures and events from the camp as much as it did for the content and insights it offers (de la Durantaye 2009, 248-9). This common criticism of Agamben's paradigmatic method, such as that made by Laclau, seems to miss or avoid taking seriously the paradigmatic methodology Agamben uses to advance his philosophical argumentation.
} 
but also an anomalous minority: we are those who by the prevarications or abilities or good luck did not touch the bottom. Those who did so, those who saw the gorgon, have not returned to tell about it or have returned mute, but they are 'Muslims', the submerged, the complete witnesses, the ones whose the position would have a general significance. They are the rule, we are the exception ... we who were favoured by fate tried, with more or less wisdom, to account not only our fate, but also that of the others, the submerged; but this was discourse on 'behalf of third parties', the story of things seen from close by, not experienced personally. (Levi 1988: 63-4)

It is this 'speaking in proxy' which Levi foregrounds that Agamben interprets in advancing his philosophical explanation of testimony. In that, for Agamben, Levi's claim that the survivor speaks in proxy for those who cannot is analogous to how experience is understood (Agamben 1999). In other words, Agamben, conceptualising his understanding of witnessing takes as its starting point Levi's account of the 'true witnesses' of Auschwitz.

Subjectivity, similar to much of Agamben's philosophical thought, is framed within his understanding of potentiality (Agamben 1999: 177). For Agamben, potentiality is the ontological principle of the possibility that there is always the potential to do something, although whether an individual does that thing or not is never predetermined (Agamben 1995: 39-49). Potentiality is not the potential of something waiting to be actualised; rather potentiality, or 'impotentiality', is the opposite to understanding events as totalising. It is the potential for an individual to 'become', but also not to become something, the eschewing of single unity of subjects. Following Agamben, an individual subject's relation to the totality of a group, such as witnesses, is the potential to only be part of that totality, which is referred to by Agamben as a 'remnant' (Agamben 1999: 87-135). Importantly, 'remnant' is the subjectivity of the subject not becoming encapsulated within the singular identity of a collective (Agamben 2005: 54). A subject understood as a 'remnant', which is the interpretation taken by this article, is a conceptual tool to see 'how a totality conceives of itself and of its component parts' (de la Durantaye 2009: 299). In short, the subject, the individual who saw the horrors of the genocide against the Tutsi, is a kind of 'remnant'. The subject as a 'remnant' is 'neither the all, nor a part of the all, but the impossibility for the part and the all to coincide with themselves or with each other' (Agamben 2005: 55). In other words, the subject framed as a 'remnant' challenges the notion that a community completely encapsulates the singularity of its members (de la Durantaye 2009: 300). From the article's perspective, it is instead the discursive conditions and thus discursive practices that constitute who can speak as the subject witness and what they can speak about. The discussion will now apply Agamben's insights on subjectivity to the investigation stage at the ICTR in order to help illustrate how this legal institution, and its actors, construct the witness subject, which entails a process 
of exclusion. Due to the word limitations of this article it is not possible to extend this discussion to some of the other pretrial legal processes at the ICTR. However, the investigation process, discussed below, is one of multiple pretrial processes, such as indictments and pretrial briefs and motions, which when viewed through the lens of subjectivity all contribute to 'filtering' who can 'become' a witness subject. The following discussion focuses on the investigators' process of selecting witnesses and investigators' lack of local knowledge.

The investigation process at the ICTR acted to restrict who can be a 'witness' through interviewing and selecting witness who had specific information that legal counsels needed to contribute to a legal judgment being reached. As former ICTR investigator David Wagala explains, investigators were only interested in witnesses who could provide relevant evidence to support the prosecutor's case. Finding the relevant witness evidence required a process of filtering out the 'irrelevant' witnesses. For example, as Wagala explicitly states:

so first we just ask [the person] general questions to ascertain that they have knowledge of what happened, because we want very good witnesses, not just people, fancy people coming here telling stories. So, the first interview is meant to identify the good potential witnesses

A further example of the pretrial stage restricting who can 'become' a witness subject at the ICTR was the Investigation Section lacking context-specific knowledge and local expertise. The ICTR was reluctant, albeit implicitly, to allow Rwandans to be part of the Office of the Prosecutor (OTP) investigation teams, or to allow judges and legal staff to visit Rwanda. The reluctance to use local expertise was based upon the concern that individuals sympathetic to the genocide as well as the Rwandan Patriotic Front (RPF) could manipulate or destroy evidence. ${ }^{5}$ Whilst it is understandable that the ICTR wanted to preserve the objectivity of investigations, the distancing of local expertise, particularly in the first decade of the tribunal, resulted in investigations being somewhat haphazard. For example, former ICTR Legal Officer Suzanne Chenault states there was a need for:

greater knowledge of the anthropological dimensions of this community. And I think that we've gone in almost like bears in a china closet without understanding Rwanda extremely well [including the] ways of approaching those who have survived and those people who witness the events.

\footnotetext{
${ }^{5}$ Interview with ICTR Prosecutor Charles Adeogun-Phillips. Interviewed by Lisa. P. Nathan and Robert Utter for the University of Washington project 'Voices from the Rwanda Tribunal'.
} 
The impact of lack of local knowledge on investigations and gathering witness evidence is also highlighted by former ICTR prosecutor Charles Adeogun-Phillips. In interview with Nathan and Utter, Adeogun-Phillips states,

[We] lacked the involvement of national staff in the investigative process. We didn't have any Rwandan help. What is the essential drawback of not having a Rwandan on your investigative team? Well, we're foreigners. We're not native to the locality and there were so many diverse issues and intricacies about the whole genocide in itself that you, you are unable to understand or grasp at a very early stage if you don't have that local context.... And you can imagine what the practical effect of that is, in the sense that we may have, based many of our trials on erroneous theories and strategies, not out of negligence, but out of ignorance.

To identify what conditions constitute the witness subject amongst all the individuals who experienced the genocide against the Tutsi, is suggested here to include investigators' lack of contextual knowledge. The uncompromising stance for legal actors to be distant from the society is evident in one senior ICTR judge's response to Clark's question, whether or not he had travelled to Rwanda?

I have never been to Rwanda and I have no desire to visit. Going there and seeing the effect we are having would only make my work more difficult. How can I do my jobjudging these cases fairly — with pictures in my mind of what is happening over there? This task is already complicated enough. (Clark 2018: 43)

The highlighting here of the complexities and in some instances incompetence of investigations is not done in order to propose procedural reform. Rather, the focus here, through a subjectivity lens, is to argue that these procedural complexities and shortfalls in investigations are an important component in understanding the discursive conditions and restrictions of how the witness subject is constituted. Drawing upon the above illustrated example, 'becoming' a witness at the ICTR entails two different but connected influences: namely investigators selecting witnesses who can tell a particular story, and the lack of investigators' contextual knowledge of Rwanda. Investigators' lack of contextual knowledge acted to shape how they understood the events of the genocide, the historical nuances leading up to it, and the complexities of the numerous actors involved. This very limited contextual knowledge in turn shaped what evidence investigators needed, including witness testimonies. Connected to, and compounding, the previous issue of lack of local knowledge, investigators' strategy for witness selection and where to seek these witnesses was directly influenced by the narrow legal narrative prosecutors/defence counsels needed in order for the court to reach a legal determination. These two distinct but intertwined issues are two examples of how the ICTR legal actors contributed to shaping the conditions and possibilities of who can 'become' a witness. In other words, the ICTR legal procedures, including 
investigations, are part of the 'filtering' process of the construction of the 'witness'. The way in which investigation teams gather evidence and respond to challenges/ issues is more than just a reflection of procedural functioning of the ICTR; crucially, they are part of restricting who can 'become' a witness.

In the next move, the article introduces Agamben's idea of the 'grey zone', which is interpreted to argue that legal witnesses at the ICTR are located in a 'grey zone'.

\section{The grey zone: law, legal witnessing, and the illusion of change}

The 'grey zone', a term Agamben takes from Levi, is where the intersection, or more specifically the conflation, of law and ethical categories exists (Agamben 1999: 22). According to Agamben, philosophical understandings of ethics encompass categories such as guilt, responsibility, and judgment as judicial as well as ethical categories. Here, it is worth briefly summarising what it is Agamben takes from Levi's concept of the 'grey zone'. This is important as the article framework uses an interpretation of Agamben's understanding when suggesting that witnesses at the ICTR are located in a 'grey zone'.

Levi's term, the 'grey zone', relates to camp detainees and the blurring of distinctions between prisoner and 'executioner' at Auschwitz; some detainees 'volunteered' for 'work' roles within the camp. One such collaborative role was the Sonderkommando (Special Squad) who were 'entrusted with running the crematoria': disposing of the bodies from the gas chambers (Levi 1988: 32). Levi discusses an unusual event, a soccer match, that took place at Auschwitz between the 'Special Squad' and SS camp guards. It is Levi's depiction of the soccer match, which Agamben uses as an example of the 'grey zone' in framing his philosophical argument on law and ethics. Levi notes how surreal the event of the soccer match was:

Men of the SS and the rest of the squad are present at the game; they take sides, bet, applaud, urge the players on as if, rather than at the gates of hell, the game were taking place on the village green (Levi 1988: 38).

For Agamben, the soccer match at Auschwitz may be incorrectly understood by some as an example of a 'brief pause of humanity' in the despairs of the horrors and atrocities taking place at Auschwitz (Agamben 1999: 26). However, Agamben argues that this 'game' is not a sign of hope. It is for Agamben the normalcy of the soccer match, which is the true horror of the Nazis' concentration camps. What Agamben appears to be pointing towards here in explaining his philosophical framing of the 'grey zone' is that what can appear as a break in the cycle of repression or violence is not in fact a rupture that signals change. Instead it is the illusion of change. Agamben's philosophical framing of the 'grey zone' encapsulates the fallacy of security and 
distance from repression and/or violence. In short, the 'grey zone' projects an interruption to unpleasant and repressive action. This interruption to the status quo has the false appearance of bringing back normalcy as the foundations for progressive change. However, the apparent appearance of normalcy is no guarantee of breaking the status quo.

Agamben's 'grey zone' is interpreted by this article as a conceptual tool, which can be used to shed light on how legal witnessing at the ICTR has the illusion of movement from a violent past to a more peaceful future. More specifically, the article's framework interpreting Agamben's 'grey zone' suggests that dominant perspectives in the legal transitional justice scholarship purporting that transformative benefits of legal witnessing facilitated by law and human rights norms, are a 'grey zone'. That being so, these dominant perspectives perceive that law facilitated through international tribunals acts as a distinct marker between a violent past and a more peaceful future (Sikkink 2011, Klinkner \& Smith 2015).

In the context of the ICTR, it is legal and human rights norms, and the witness testimonies they facilitate, that give the illusion of a linear progression to a brighter horizon. Here the illusion is the claim of advocates that law makes past atrocities understandable in the present and thus makes a society's transition to a peaceful future possible. It is suggested here that understanding legal witnessing as being located in a 'grey zone' allows this claim to be exposed as unhelpful and misguided. For example, in the Nizeyimana case the prosecutor called thirty-eight witnesses to testify in court and the defence called thirty-nine witnesses (Nizeyimana Judgment and Sentencing 2012: 450-1). Although the prosecutor's pretrial brief stated the names and summaries of what they would testify to in court for fifty witnesses, twelve less than that actually testified on the witness stand (Nizeyimana Pre-trial brief 2010). One month prior to the submission of the pretrial brief the prosecutor filed a memorandum titled 'Compliance with the scheduling order' (2010). This document stated the names of seventy-one witnesses that the prosecution would call during the trial (Prosecution Memorandum 2010: 1-9). In short, in the Nizeyimana case the number of witnesses who were to testify in court was reduced from seventy-one to thirty-eight, a reduction of thirty-three witnesses. This does not include witness statements that may have been gathered by investigators but not included in the scheduling order or pretrial brief. In short, understanding legal witnessing as being located in a 'grey zone' casts light upon the fragmented and very limiting process of who can be a 'witness' and what they can talk about at the ICTR.

Understanding legal witnessing as a 'grey zone' is crucial to challenging the claim in legal transitional justice scholarship that international criminal law is the primary response to mass atrocities, not only in addressing impunity but also in making sense of past violence (Turner 2016). In other words, international criminal law is unable to 
provide a linear progression from a violent past to a more peaceful future. For example, advocates claim that international criminal law has transformative benefits that are upheld through the universality of legal and human rights norms (Sikkink 2011). This claim is linear and can be explained thus. The horrors of genocide against the Tutsi were allowed to happen because legal and human rights norms were ignored. The response to this - indeed the only response - is international criminal law. The ICTR represents the re-establishing of legal and human rights norms. Law, having been re-established through the creation of the ICTR, is able to make sense of past atrocities. Having made sense of past rights violations via witness testimonies, law has facilitated an essential component of transition, an understanding of social and political reasons for the violence occurring.

However, the claim described above is a self-filling prophecy of law. This prophecy is at the crux of the claim that international criminal law, and international criminal institutions such as the ICTR, are a suitable response for making sense of mass violence in the present. In short, this circular prophecy of law is the failure of law, law being restored, and law facilitating progress via the testimonies of witnesses. Importantly, law through the universality of legal norms has the illusion of breaking the status quo of violations of human rights and provides positive change towards a brighter future. This is the essence of the 'grey zone' of legal witnessing: an illusion of change, not actual change.

\section{The lacuna of law and justice or legal witnessing as 'judgment'}

By decoupling law from justice Agamben states that, ontologically, law is solely about 'judgment' absent of justice and truth. For the purpose of the article's conceptual framework, it is Agamben's insights on the need for distance to be drawn in lawjustice understood as one and the same thing. To be clear, the article is specifically interested in Agamben's insights on the relationship, or lacuna, between law and justice, rather than directly engaging with his thinking on law. ${ }^{6}$ Here it is also worth acknowledging that the article interprets this insight of Agamben. Specifically, the article does not follow Agamben all the way in seeking the deactivation, or removal of law, in order for justice to be reached (Agamben 1999). Although, the article does agree with Agamben that law and justice are distinct. In short, using Agamben's insights on the lacuna of law and justice is not to argue that transitional justice should seek the removal of law for justice to be possible for transitioning societies. Rather, his insights are interpreted as a conceptual tool to argue the need to unshackle the fallacy

\footnotetext{
${ }^{6}$ For discussion on Agamben's understanding of law see Agamben (1995); Zartaloudis (2010); Frost (2014).
} 
of a transcendent synthesis at international tribunals (ICTR). This fallacy is the conflation of legal determination and the capacity of law to contribute to making sense of the past in deeply divided societies: the law's (in)ability to facilitate social change.

For Agamben, lacuna, or 'threshold', is a key conceptual device that he uses throughout his ontological oeuvre, including the separation of law-justice, to foreground 'the undoing of our structured and imposed forms of subjectivity' (Murray 2010: 100). Crucial to Agamben's ontological understanding of the lacuna is the relationship between law and justice, or more directly put, the need to draw distance within the notion that law and justice are one and the same thing. Law is only about 'Judgment' (Agamben 1999). For Agamben, law-justice as inseparable is a fallacy that entrenches the idea that through the applications of law, justice is unequivocally attainable. According to Agamben, there is no origin or foundation of law that it is possible to return to that would allow for the fulfilment of justice (Agamben 1995). Following Agamben, Frost has highlighted that justice understood as 'potentiality' requires the 'messianic' deactivation of the law (Frost 2014). To deactivate the law is not the destruction of law or to move beyond the law. Rather to 'deactivate' the law, or the messianic deactivation of the law, is the 'gate' that can lead to justice (Agamben 1995, Frost 2014: 219). The messianic deactivation does not mark the completion of law where justice is achieved. Rather, law is what must be " "fulfilled" in the passage to justice' (Whyte 2010: 111). As Agamben argues, 'law is not directed toward the establishment of justice. Nor is it directed toward the verification of truth. Law is solely directed toward judgment, independent of truth and justice' (Agamben 1999: 18). In short, the article interprets Agamben's understanding of the 'witness', discussed above, and the distancing of law-justice discussed here, in order to argue that legal witnessing at the ICTR should be understood as located in a lacuna between legal determination and justice-truth: 'judgment'.

This understanding challenges the common perception within legal transitional justice scholarship of a transcendent synthesis of legal determination and the capacity of international criminal law to make sense of a violent past. For example, according to Sikkink (2011), human rights trials necessarily address mass rights violations through judicial accountability. Simultaneously judicial accountability through the application of international law allows for those violations to be understood (Sikkink 2011). In other words, for scholars such as Sikkink (2011) the ICTR reaching a legal determination of guilt or innocence and related judgment is inherently tied up with being able to make sense of past violations. Legal determination and law's ability to make sense of past horrors are one and the same thing. For the article, understanding law-justice as distant from each other is an important conceptual tool to argue that the ontological distancing of law-justice produces a lacuna in which the myth 
that legal and human rights norms facilitate a transcendent synthesis from legal determination to understanding a traumatic past can be exposed.

In societies such as Rwanda, affected by conflict and atrocities, there are numerous understandings of justice, including judicial, semi-legal, or hybrid like gacaca, and non-judicial processes including community therapy, and ritual and faith healing processes (Macdonald \& Allen 2015). The importance for scholars and courts to engage with local articulations of justice are also mirrored in the words of one Rwandan genocide survivor,

This man is in Arusha and I am only hearing that he is being tried but it is very far away and it does not help. Can you testify against someone we do not see? To speak would reduce our suffering and I hope that he will be punished but no one has come to speak to us about what he did. How can they try someone if they do not hear our stories? If he came here, maybe he could ask for forgiveness, and perhaps we could have forgiven him. Over there, it does not follow the way of justice that we expect. (Clark \& Palmer 2012: 12)

In summary, Agamben states that it is not the case that law and the witness testimonies it facilitates mean justice has been achieved (Agabmen 1999). Or to put it slightly more crudely, witnesses testifying in court is not a box to be 'ticked' indicating justice has been reached. Instead, understanding legal witnesses in the lacuna of law and justice is a way to resist international criminal law's need for progress and singularity. The testimonial evidence witnesses give in court serves an important function of contributing to a legal determination being reached. However, testimony's contribution should not be understood beyond its judicial contribution. The witness located in the lacuna between law and justice then means that testimony is not about contributing towards an understanding of the past, and reaching that understanding would be an important part of a society's progress to a more peaceful future. Instead, the act of witnesses testifying in court becomes distinct from any notions of justice. The act of testimony distinct from justice is important because it resists transitional justice's legalistic impulse to assume that international criminal law is transformative.

\section{Remembering with others}

Ricœur understands memory to be both individual and collective, rejecting the polemical positing that memory is either individual or collective. Underwriting Ricœur's rejection of a binary understanding of memory is the idea that, if memory belongs purely to the individual, it does not seem possible to have a genuine sense of communal memory. Conversely, if memory is only collective, our understanding 
of memory is separated from the memories of individual subjects (Ricœur 2004: 45-50). ${ }^{7}$ For Ricœur, it is necessary to denounce the 'inwardness' position that the origins of memory can only reside within the individual. However, he also challenges the claim that memory is unequivocally 'communal'. Specifically:

Does not the very act of 'placing oneself' in a group and of 'displacing' oneself or shifting from group to group presuppose a spontaneity capable of establishing a continuation with itself? If not, society would be without any social actors. (Ricœur 2004: 122)

For Ricœur, conceptualising 'memory' requires a middle ground, 'between the self and they' (Ricœur 2004: 132); a framing of memory that is inclusive of the 'inwardness' perspective of agency whilst also allowing for the 'collective' sharing of memories with 'others'. This middle ground proposed by Ricœur entails being in close proximity with 'others'. That is, being close to 'others' (groups) whilst at the same time maintaining a relation to the self; between the private solitary individual and public communal life (Ricœur 2004: 132). '[C]lose relations are individuals who approve of my existence and whose existence I approve of in the reciprocity and equality of esteem' (Ricœur 2004: 132). It is with 'close relations' that an individual can speak and remember, and, importantly, includes those who may not approve of an individual's actions though they do not dismiss the individual's experience. In other words, being close to 'others' is the capacity to share stories of the past with 'others' and have a collective understanding of events without individuals being reduced to the collective identity of a group, such as legal witnesses. Sharing stories 'with others', Ricœur suggests, is what forms a 'life in common' (Ricœur 2004: 131-2). Specifically, a shared understanding of a traumatic past is not located in what a given community (group) remembers about itself. Rather it is the stories of individuals which they tell each other about the origins of their shared experience of past events (Leichter 2012). It is the plural stories of individuals and heterogeneous experiences communally shared that forms a 'life in common' with 'others' (Ricœur 2004: 131-2).

Extending the argument above on the 'grey zone', the following discussion argues that the construction of legal memories at the ICTR lacks plural memories (Ricœur 2004). Specifically, engaging with Ricœur's conceptual insights on the plurality of memory, it is argued that the discursive conditions at the ICTR are commonly unable to engage with plural memories. These memories are an essential component for communities sharing stories about the past.

${ }^{7}$ Jeffery Olick takes a similar position that 'There is no individual memory without social experience, nor is there any collective memory without individuals participating in communal life' (Olick 2007: 34). 
In the context of the claim that the ICTR can produce a collective memory of past violence, Ricœur's concept of the plurality of memory allows the article to critique this claim (Klinkner \& Smith 2015, Keydar 2019). The ICTR produces a narrow and singular memory for the specific purpose of reaching a legal judgment. The discursive conditions that constitute what witnesses can talk about, as illustrated above in the context of ICTR investigations, do not include individuals sharing heterogeneous memories of shared past events with their community. Plural memories of the dynamics of genocidal violence are absent from the legal story. Witness memories that are included in statements gathered by investigators, in indictments and pretrial briefs also lack plurality; instead, they need to fit within the singular legal categories of ICTR crimes.

Importantly, what is also absent from the narrow legal memory the ICTR produces is the remembering 'with others' that is a key part of memory (Ricœur 2004). The ICTR did not facilitate a platform for individuals to externalise their memories of shared past experiences with each other. In fact, it is not the purpose of international criminal tribunals and courts to be a platform for communities exchanging personal experiences of a violent past with each other. On a related point, even the singular and narrow memory the ICTR produces is out of reach for most Rwandans, in consideration of the geographical distance of the court from Rwanda. For most Rwandans the ICTR being located hundreds of miles away in Arusha, Tanzania, has meant court proceedings where witness memories are externalised is something they have not experienced (Palmer 2015). This legal distancing from the context of the violence goes beyond just geography. It also represents the view of advocates that international criminal and human rights law should be distant from the events it is judging so as not to be 'contaminated' by what is seen and heard on the ground (Clark 2018). Despite the ICTR's rhetoric that their outreach programmes have helped make the workings of the court known to Rwandans, the reality for most Rwandans is that the ICTR remains in all senses distant (Schulz 2017, Clark 2018). This distancing is reflected in the statement of one gacaca judge remarking on justice in Rwanda,

In Arusha the big fish are there. The victims travel there, but in gacaca, everyone is already here: survivors, perpetrators, judges, they are all here in the community. That is the difference ... . Those in Arusha haven't asked for forgiveness, yet they have committed many crimes here. They should face us, the Rwandan family, but they avoid us by being there. (Clark \& Palmer 2012: 12)

This distancing of the ICTR adds to the evidence that the tribunal lacks the core component of memory, individuals telling plural experiences to their community. In short, even the narrow legal memory the ICTR produced lacks communal remembering, which is essential for the sharing of heterogeneous experience of past violence. 
To help illustrate the ICTR's shortage of plural memories, the following discussion will briefly use the example of the Rwandan gacaca courts, which in contrast to the tribunal did facilitate plural memories (Clark 2010, Palmer 2015, Doughty 2016, Thorne \& Viebach 2019). The gacaca courts (2002-12) were used before and during colonialism as a community-based conflict resolution mechanism and were adapted and modernised to try crimes including Genocide and Crimes Against Humanity (Clark 2010). Central to gacaca was its restorative element that included participation of the whole community (Clark 2010). Legal and human rights norms are central to the claim that the ICTR can produce a collective memory of violence. Interestingly, as gacaca did not adhere to these norms, legal and human rights groups concluded that gacaca was a failure (Thorne \& Viebach 2019). ${ }^{8}$ Importantly, it is precisely the localised understanding of justice at gacaca that allowed for communities to share diverse individual stories of violence (Doughty 2016, 2017). The decision by the Rwandan government to use this traditional justice mechanism is what facilitated community dialogue about diverse experiences of genocidal violence (Clark 2010: 320). A key part of gacaca's mandate was community reconciliation through victims, witnesses, perpetrators, and members of the community being able to ask questions about the past. In part, it is precisely gacaca not adhering to legal and human rights norms, that are so entrenched at the ICTR, which allowed for the communal sharing of individual plural experiences of genocidal violence (Doughty 2016). In other words, the example of gacaca illustrates that the absence of plural memories at the ICTR is explicitly related to its discursive conditions and legal norms. In contrast, gacaca for many Rwandans, although not all, allowed the sharing in communities of individual experiences of genocidal violence through localised understandings of justice.

In short, Ricœur's insights on the plurality of memory have been used to argue that the ICTR lacks plural memories of experiences of the past. This conceptual lens challenges the claim that the ICTR is able to produce a legal collective memory of mass violence.

\footnotetext{
${ }^{8}$ Viebach and I (Thorne \& Viebach 2019) have argued that reports produced by rights groups (Human Rights Watch and Amnesty International) have concluded gacaca as a failure because it did not adhere to Western standards of legal and human rights reports. Crucially, these human rights reports tell a story that leaves little room for different interpretations or meanings attached to gacaca and therefore it is not able to understand the positive impact gacaca has for many Rwandans. Instead these reports produce a very limited understanding of gacaca, which is rooted in the radical exclusion of context, subjectivity, sociality, and material belonging (Thorne \& Viebach 2019).
} 


\section{Legal memory as 'manipulated memory'}

Whilst the sharing of heterogeneous memories of the past with groups is for Ricœur an important component of 'memory', Ricœur does acknowledge that collective understanding of the past produced through individual experiences can potentially be problematic, particularly the institutional production of memory. Ricœur users the term 'manipulated memory' in relation to institutionalised production of memory (Ricœur 2004: 80). Specifically, the institutionalised production of memory entails strategies including the intentional omission of certain facts and the promotion of others, and a contextual narrative emphasising a causal relationship between events. For Ricœur it is within 'manipulated memory' that ideology functions, justifying power 'that the resources of manipulation provided by narrative are mobilised' (Ricœur 2004: 85). According to Ricœur, the institutional construction of the past, manipulated memory, centres around the legal demand for the public expression of memory (Ricœur 2004: 220). Crucially, manipulated memory in international legal institutions is centred around hierarchical systems of power and order that legitimise certain courses of action. For Ricœur, the production of institutional knowledge of past events is legitimised through a hierarchical relation between the agency of certain actors being enacted over actors with less or no agency (Ricœur 2004: 83). In the context of this article, the ICTR is understood as entailing a system of power that structures and legitimatises certain knowledge, memories of the past, whilst simultaneously constraining other forms of knowledge. Here, applying the lens of manipulated memory to the construction of memory at the ICTR aids our thinking about how this legal institution and its actors, such as legal counsel, play an important role in what memories of past horrors are heard at the ICTR. Legal counsels are not concerned with witnesses externalising their memories of traumatic experiences (Eltringham 2019: 135). Legal counsel focus on just a very small part of a witness's experience that the counsel needed in order to tell their legal narrative. Sometimes this tiny piece of information that was so vital to the lawyer seemed an unimportant part of the story for the witness. As one ICTR prosecution lawyer told Eltringham,

[w]e only need ten or fifteen minutes out of their whole lifetime. We're only interested in a tiny little part. We're not interested in the before or the after. They can't understand why this miniscule incident is so important. ... They want to talk about other things. Therefore, they're frustrated, they're not fulfilled because they haven't told their story (Eltringham 2019: 135).

Powerful actors within the ICTR are key to the way in which particular individuals and their experiences are used or discarded, depending on the objectives and motivation of those actors who have the power to construct memory (Ricœur 2004: 80-5). 
Legal actors, such as lawyers, as powerful individuals in the process of memory production at the ICTR relate to the legal demand for trials of mass atrocities to make public what were previously personal private memories (Felman 2002, Ricœur 2004: 220). As Felman reminds us, law is incapable of telling stories of mass violence, but that is exactly what law must do (Felman 2002). International criminal law making public what were previously private individual memories is the process whereby powerful actors, such as legal counsels and judges, justify certain outcomes that shape and influence what memories become part of the publicly told collective legal story.

In summary, this section has outlined a conceptual framework in order to deconstruct witness identity and memory at the ICTR. Applying this conceptual lens to the ICTR shows that the witness who speaks in court is speaking on behalf of, or as a proxy for, the true witness. This shows that the knowledge of the past witnesses speak about is always partial. Related to this, what witnesses are is not self-evident, and a term like witness does not encapsulate the entire group. A particular value of this argument is that it redirects the focus away from assuming that what witnesses are is self-evident and instead focuses on how an individual 'becomes' a witness. Secondly, witness memories are something constructed through a process of inclusion and exclusion by institutions, such as the ICTR and its actors. Furthermore, memory production is a dispersed process entailing numerous layers and levels, and entails people sharing past experiences with each other. The arguments made in this section offer one alternative understanding of the ways in which the ICTR constructs witness identities and memory. In doing so, the arguments contribute to extending legal scholarship's understanding of legal witnessing at the ICTR. Whilst it is the case that the processes and systems of each court and tribunal will vary, it is likely that the argument advanced in this article would be apparent in all instances of international criminal tribunals and legal witnessing.

As the theme of this supplementary issue is transitional justice in Africa, this concluding section reflects on Rwandan society's relationship with legal memory. Specifically, it is proposed here that legal witnesses can potentially contribute to the post-conflict memory ecology during periods of transition, although, crucially, this requires a conceptual reorientation in how we think about legal memory. It will be proposed that, if we re-orientate our understanding of legal memory away from court proceedings and instead zoom in on the legal archive, and the material it houses, this can potentially be a way that legal witnesses can contribute to post-conflict memory ecology in Rwanda. 


\section{Fragments of legal memories}

This final discussion conceptually explores the potential role ICTR archival material could have in aiding post-conflict memory ecology in Rwanda. It does this by conceptually exploring what else the legal process of memory construction does: what else happens or is produced through the institutional conditions and possibilities at the ICTR. In short, this final discussion explores one way not to be limited by international criminal law's need for singularity and progress, and therefore puts front and centre the plural and multidirectional nature of remembering atrocities.

\section{Legal archives: plurality, self, and 'others'}

The discussion explores the potential for fragments of witness memories contained in the ICTR archive material to contribute to post-genocide memory ecology in Rwanda. These fragments include witness statements and testimonies, along with other material, including forensic reports, investigators' dossiers, videos of investigation sites, diaries, letters, and photographs from pre-genocide, genocide, and post-genocide periods. Some of this material was used during trials, but not all. The unused materials were not deemed relevant to the narrow legal narrative lawyers need to tell in contributing to reaching a legal determination of guilty or not guilty. However, this does not necessarily mean these materials are unreliable or not potentially meaningful and important to Rwandan communities and individuals. It is the fragmented and nonlinear space of legal archives that can contribute to the plurality of meaning in how societies make sense of and move beyond past horrors.

Here it is suggested that we consider the ICTR archival material to consist of relational fragments of memories, and how these fragments could contribute towards Rwandan's sharing plural experiences of the past. Emmanuel Levinas (2001) refers to relationality as having at its essence the irreducible relation between oneself and other people, which Levinas refers to as the 'Other' (Levinas 2001: 33-40, Frost 2014: 223). For Levinas, awareness of objects by the self, or I, leads to the awareness of the 'Other'. It is this awareness of the 'Other' that is relational (Levinas 2001: 104-18). The 'Other' exists before the self; in fact, it is the Other that constitutes the self. Importantly, as Frost argues, the Other constituting the self 'does not drive the I into any particular outcome. Nor does the relation to the Other have any meaning apart from constituting the I, the Self' (Frost 2014: 227). In short, Levinas's concept of relationality is interpreted here as a way to think about archival material existing as individual fragments but in relation to other fragments, though importantly the relation is not predetermined or presupposing the memory into a group or identity. 
Relationality is being used in two interconnecting ways: fragments of experiences in the ICTR archive material are connected but not determined into a dominant narrative, and Rwandans have relational existence to plural experiences of the past. In summary, relationality is suggested here as a useful way to think about transitioning societies' relationships with legal memory that highlights the existence of fragments of the past telling multiple stories. Legal memory in the form of fragments of experiences in the archive material, including witness testimonies, exist as relational fragments. Each fragment of memory exists in relation to other fragments but, unlike the narrow legal memory the ICTR produces, these fragments have not been defined within a dominant narrative of the past.

To help illustrate how relational fragments of memories in the ICTR archive could contribute to plural memory ecology in Rwanda, an example using photographs will now be used. Specifically, it is suggested here that archival photographs could be a productive way to stimulate intergenerational transmission of memories that engages with the diverse memory ecology in Rwanda: between individuals who experienced the genocide against the Tutsi and those born during/afterwards and thus with no personal memories of the events of 1994.

The ICTR archives contain hundreds of photographs, including family photographs, photographs taken by journalists during the genocide against the Tutsi, and photographs taken by ICTR investigators. Many of the photographs are of places that the post-genocide generation would likely know and may also be part of their everyday reality: shops, football stadiums, and churches. For example, photographs taken after the genocide by ICTR investigators of places where genocidal violence occurred, such as high streets and football stadiums, could be a way of facilitating a dialogue between generations. ${ }^{9}$ In particular, some of these images will be part of the post-genocide generation's everyday lived reality, physical spaces that they know and interact with on a regular basis. Having familiarity with the places in these photographs means it is likely that individuals born after the genocide will have a collection of stories, or fragments of memories, associated with these places. These images could be used as a starting point to facilitate a conversation between those who experienced the horrors of 1994 and those with no personal memories. In particular, as both types of individual will have stories of these places, it would allow for multiple meanings to be discussed. Photographs are not a site where meaning is given; rather they are spaces where meanings are sought and negotiated (Fairey \& Orton 2019). In the Rwandan context, photographs from the ICTR archive offer an opportunity for meanings of Rwanda's past to be sought and negotiated between generations. Photographs can

${ }^{9}$ For an example of the importance of photographs in how some Rwandans come to terms with and manage their past trauma, see Piotr Cieplak's documentary The Faces We Lost (2017). 
stimulate dialogue about human experiences because imagery is explicitly orientated towards embracing complexity and the plurality of lived experiences (Azoulay 2012). Photographs carry with them the potential for perspectives to be explored, reinforced, challenged, and altered, and are the beginning of a conversation (Fairey \& Orton 2019: 299). Photographs as a tool for dialogue are 'enmeshed in webs of power, resistance and agency through which we assert and explore a sense of self and relation to others' (Fairey \& Orton 2019: 299). Dialogue through photographs is a process of being with, and being open to, others, experiencing the world of and with other people (Fairey \& Orton 2019: 301). ICTR archival photographs as a dialogue to engage with other people and their experiences speak directly to Levinas's idea of the 'Other' and Ricœur's plurality of memory. It is suggested that archival material, fragments of memory, have great potential to aid the plurality of post genocide memory ecology in Rwanda.

\section{Acknowledgments}

Firstly, I would like to thank the guest editorial team of this supplementary issue for bringing together such an interesting and important set of papers on this crucial topic. I would like to also thank Dr Matthew Evans, Dr Tom Frost, and Dr Tarik Kochi for the many readings and comments on my $\mathrm{PhD}$ thesis which this article is founded upon. Additionally, many thanks to Tom for the numerous conversations on Agamben and critical legal theory more broadly which has undoubtedly further developed my understanding and its application to the context of transitional justice. Also thank you for the comments and feedback from the two anonymous reviewers which helped further develop this article.

\section{References}

Agamben, G. (1995), Homo Sacer: Sovereign Power and Bare Life (Stanford, CA, Stanford University Press).

Agamben, G. (1999), Remnants of Auschwitz: The Witness and the Archive (Princeton, NJ, Zone Books). Agamben, G. (2005), The Time that Remains: A Commentary on the Letter to the Romans (Stanford, CA, Stanford University Press).

Ambos, K. (2009), “"Witness Proofing” Before The ICC: Neither Legally Admissible Nor Necessary', in The Emerging Practice of the International Criminal Court (Leiden, Brill), 599-614. https://doi.org/10.2139/ssrn.1972144

Azoulay, A.A. (2012), Civil Imagination: A Political Ontology of Photography (London, Verso Books).

Bernstein, J.M. (2004), 'Bare Life, Bearing Witness: Auschwitz and the Pornography of Horror', parallax, 10(1): 2-16. https://doi.org/10.1080/1353464032000171046 
Clark, P. (2010), The Gacaca Courts, Post-genocide Justice and Reconciliation in Rwanda: Justice Without Lawyers (Cambridge, Cambridge University Press). https://doi.org/10.1017/CBO9780511761584

Clark, P. (2018), Distant Justice: The Impact of the International Criminal Court on African Politics (Cambridge, Cambridge University Press). https://doi.org/10.1017/9781108576260

Clark, P. \& Palmer, N. (2012), Testifying to Genocide: Victim and Witness Protection in Rwanda (London, Redress Trust).

Clarke, K.M. (2019), Affective Justice: The International Criminal Court and the Pan-Africanist Pushback (Durham, NC, Duke University Press). https://doi.org/10.1215/9781478007388

Combs, N.A. (2010), Fact-finding Without Facts: The Uncertain Evidentiary Foundations of International Criminal Convictions (Cambridge, Cambridge University Press). https://doi.org/10.1017/CBO9780511760259

de la Durantaye, L. (2009), Giorgio Agamben: A Critical Introduction (Stanford, CA, Stanford University Press).

Dixon, P. \& Tenove, C. (2013), 'International Criminal Justice as a Transnational Field: Rules, Authority and Victims', International Journal of Transitional Justice, 7(3): 393-412. https://doi.org/10.1093/ijtj/ijt015

Doughty, K.C. (2016), Remediation in Rwanda: Grassroots Legal Forums (Philadelphia, PA, University of Pennsylvania Press).

Doughty, K.C. (2017), Inside Rwanda's Gacaca Courts: Seeking Justice After Genocide (Madison, WI, University of Wisconsin Press).

Eltringham, N. (2019), Genocide Never Sleeps (Cambridge, Cambridge University Press). https://doi.org/10.1017/9781108757195

Fairey, T. \& Orton, L. (2019), 'Photography as Dialogue', Photography and Culture, 12(3): 299-305. https://doi.org/10.1080/17514517.2019.1669992

Felman, S. (2002), The Juridical Unconscious: Trials and Traumas in the Twentieth Century (Cambridge, MA, Harvard University Press).

Foucault, M. (1972), The Archaeology of Knowledge (New York, Pantheon).

Frost, T. (2014), 'Thinking Relationality in Agamben and Levinas', Griffith Law Review, 23(2): 210-31. https://doi.org/10.1080/10383441.2014.962682

Groome, D. (2011), 'The Right to Truth in the Fight against Impunity', Berkeley Journal of International Law, 29: 175-99.

ICTR (International Criminal Tribunal for Rwanda) (2007), Statute: Article 31 Rules of Procedure and Evidence (Arusha, United Nations).

ICTR (International Criminal Tribunal for Rwanda) (2010), Statute: Article 17 Investigation and Preparation of Indictment (Arusha, United Nations).

Igwe, C.S. (2008), 'The ICC's Favourite Customer: Africa and International Criminal Law', The Comparative and International Law Journal of Southern Africa, 41(2): 294-323.

Jones, N. (2009), The Courts of Genocide: Politics and the Rule of Law in Rwanda and Arusha (Abingdon, Routledge).

Kendall, S. (2015), 'Beyond the Restorative Turn: The Limits of Legal Humanitarianism', in C. De Vos, S. Kendall \& C. Stahn (eds) Contested Justice: The Politics and Practice of International Criminal Court Interventions (Cambridge, Cambridge University Press), 352-76. https://doi.org/10.1017/CBO9781139924528.017

Keydar, R. (2019), 'Mass Atrocity, Mass Testimony, and the Quantitative Turn in International Law', Law \& Society Review, 53: 554-87. https://doi.org/10.1111/lasr.12399

Klinkner, M. \& Smith, E. (2015), 'The Right to Truth, Appropriate Forum and the International Criminal Court', in N. Szablewska \& S.-D. Bachmann (eds) Current Issues in Transitional Justice: Towards a More Holistic Approach (Cham, Springer International), 3-29.

https://doi.org/10.1007/978-3-319-09390-1_1 
Leichter, D.J. (2012), 'Collective Identity and Collective Memory in the Philosophy of Paul Ricœur', Ricoeur Studies/Etudes Ricoeuriennes, 3(1): 114-31. https://doi.org/10.5195/ERRS.2012.125

Levi, P. (1988), The Drowned and the Saved trans R. Rosenthal (London, Michael Joseph) (originally published 1986).

Levinas, E. (2001), Is it Righteous to Be? Interviews with Emmanuel Levinas ed. J. Robbins (Stanford, CA, Stanford University Press).

Macdonald, A. \& Allen, T. (2015), 'Social Accountability in War Zones - Confronting Local Realities of Law and Justice', International Journal on Minority and Group Rights, 22(3): 279-308. https://doi.org/10.1163/15718115-02203001

Madlingozi, T. (2010), 'On Transitional Justice Entrepreneurs and the Production of Victims', Journal of Human Rights Practice, 2: 208-28. https://doi.org/10.1093/jhuman/huq005

Marion, E.N. (2006), 'The Nazi Genocide and the Writing of the Holocaust Aporia: Ethics and Remnants of Auschwitz', MLN: Modern Language Notes, 121(4): 1009-22. https://doi.org/10.1353/mln.2006.0098

McEvoy, K. (2007), 'Beyond Legalism: Towards a Thicker Understanding of Transitional Justice', Journal of Law and Society, 34(4): 411-40. https://doi.org/10.1111/j.1467-6478.2007.00399.x

Mouffe, C. \& Laclau, S. (2007) En torno a lo político (Buenos Aires, Fondo de cultura económica).

Muleefu, A. (2019), The Independence of the International Criminal Court: Between a Rock and a Hard Place (Cambridge, Intersentia). https://doi.org/10.1017/9781780688992

Murithi, T. (2008), 'The African Union's Evolving Role in Peace Operations: The African Union Mission in Burundi, the African Union Mission in Sudan and the African Union Mission in Somalia', African Security Studies, 17(1): 69-82. https://doi.org/10.1080/10246029.2008.9627460

Murray, A. (2010), Giorgio Agamben (Abingdon, Routledge). https://doi.org/10.1080/10246029.2008.9627460

Nathan, L.P., Lake, M., Grey, N.C., Nilsen, T., Utter, R.F., Utter, E.J., Ring, M., Kahn, Z. \& Friedman, B. (2011), 'Multi-lifespan Information System Design: Investigating a New Design Approach in Rwanda', in Proceedings of the 2011 iconference: 591-7. https://doi.org/10.1145/1940761.1940841

Nizeyimana Judgment and Sentencing (2012), Mechanism Archives and Records Section, ICTR-0055C-05361, 22 June 2012 (Arusha, United Nations).

Nizeyimana Pre-trial brief (2010), 'Reply To Prosecutors Response To Urgent Pre-Trial Motion For Disclosure Under Rule 66(A) (Ii) Of The R.P.E', Mechanism Archives and Records Section, ICTR00-55C-017, 14 December 2010 (Arusha, United Nations).

Nkansah, L.A. (2011), 'International Criminal Justice in Africa: Some Emerging Dynamics', Journal of Politics and Law, 4(2): 74-84. https://doi.org/10.5539/jpl.v4n2p74

Nyawo, J. (2017), Selective Enforcement and International Criminal Law: The International Criminal Court and Africa (Cambridge, Intersentia). https://doi.org/10.1017/9781780685014

Olick, J.K. (2007), 'Collective Memory and Nonpublic Opinion: A Historical Note on a Methodological Controversy about a Political Problem', Symbolic Interaction, 30(1): 41-55. https://doi.org/10.1525/si.2007.30.1.41

Palmer, N. (2015), Courts in Conflict: Interpreting the Layers of Justice in Post-Genocide Rwanda (Oxford, Oxford University Press). https://doi.org/10.1093/acprof:oso/9780199398195.001.0001

Prosecution Memorandum (2010), 'Supplementary Submission To The Motion To Vary The Witness List', Mechanism Archives and Records Section, ICTR-00-55-0125, 14 September 2010 (Arusha, United Nations).

Ricœur, P. (2004), Memory, History, Forgetting (Chicago, IL, University of Chicago Press). https://doi.org/10.7208/chicago/9780226713465.001.0001

Sikkink, K. (2011), The Justice Cascade: How Human Rights Prosecutions Are Changing World Politics (The Norton Series in World Politics; New York, W.W. Norton). 
Thoms, O., Ron, J. \& Paris, R. (2008), 'The Effects of Transitional Justice Mechanisms. A Summary of Empirical Research Findings and Implications for Analysts and Practitioners' (University of Ottawa, Ottawa, Centre for International Policy Studies).

Thorne, B. \& Viebach, J. (2019), 'Human Rights Reporting on the Rwandan Gacaca Courts: A Story of Stagnation and Failure', in H. Grayson \& N. Hitchcott (eds) Rwanda Since 1994: Stories of Change (Liverpool, University of Liverpool Press). https://doi.org/10.2307/j.ctvh9vw0t.6

Teitel, R.G. (2015), Globalizing Transitional Justice: Contemporary Essays (Oxford, Oxford University Press). https://doi.org/10.1093/acprof:oso/9780195394948.001.0001

Turner, C. (2013), 'Deconstructing Transitional Justice', Law Critique, 24: 193-209. https://doi.org/10.1007/s10978-013-9119-z

Turner, C. (2016), Violence, Law and the Impossibility of Transitional Justice (Abingdon, Routledge). https://doi.org/10.4324/9781315695044

United Nations (1994), Resolution 955. https://digitallibrary.un.org/record/198038? ln=en

VFRT (Voices from the Rwanda Tribunal), Suzanne Chenault, Legal Officer and Juris-Linguist. Interview Date: 4 November 2008 Location: Arusha, Tanzania Interviewers: Lisa P. Nathan Donald J Horowitz.

http://www.tribunalvoices.org/voices/transcripts/transcript_CHENAULT_Suzanne_full.pdf

VFRT (Voices from the Rwanda Tribunal), Everard O'Donnell, Deputy Registrar. Interview Date: 15 October 2008 Location: Arusha, Tanzania Interviewer: Donald J Horowitz. http://www.tribunalvoices.org/voices/transcripts/transcript_ODONNELL_Everard_full.pdf

VFRT (Voices from the Rwanda Tribunal), David Wagala, Acting Chief of Investigations. Interview Date: 16 October 2008 Location: Butare, Rwanda Interviewers: Batya Friedman John McKay. http://www.tribunalvoices.org/voices/transcripts/transcript_WAGALA_David_full.pdf

Whyte, J. (2010), 'A New Use of the Self': Giorgio Agamben on the Coming Community', Theory \& Event, 13(1). https://doi.org/10.1353/tae.0.0115

Zartaloudis, T. (2010), Giorgio Agamben: Power, Law and the Uses of Criticism (Abingdon, Routledge). https://doi.org/10.4324/9780203859711

Zunino, M. (2018), Justice Framed (Cambridge, Cambridge University Press). https://doi.org/10.1017/9781108693127

To cite the article: Benjamin Thorne (2021), 'Liberal international criminal law and legal memory: deconstructing the production of witness memories at the International Criminal Tribunal for Rwanda', Journal of the British Academy, 9(s2): 127-154. DOI https://doi.org/10.5871/jba/009s2.127

Journal of the British Academy (ISSN 2052-7217) is published by The British Academy, 10-11 Carlton House Terrace, London, SW1Y 5AH www.thebritishacademy.ac.uk 